\title{
Analysis of the expression of toll-like receptors 2 and 4 and cytokine production during experimental Leishmania chagasi infection
}

\author{
Glaucia Aparecida Gomes Cezário ${ }^{1 /+}$, Larissa Ragozo Cardoso de Oliveira ${ }^{1}$, Eliana Peresi ${ }^{1}$, \\ Vanessa Cristina Nicolete', Jossimara Polettini' ${ }^{2}$, Carlos Roberto Gonçalves de Lima', \\ Mariana Gatto', Sueli Aparecida Calvi ${ }^{1}$ \\ ${ }^{1}$ Departamento de Doenças Tropicais \\ ${ }^{2}$ Departamento de Patologia, Faculdade de Medicina de Botucatu, Universidade Estadual Paulista, Botucatu, SP, Brasil
}

\begin{abstract}
Toll-like receptors (TLRS) recognise pathogen-derived molecules and influence immunity to control parasite infections. This study aimed to evaluate the mRNA expression of TLRs 2 and 4, the expression and production of the cytokines interleukin (IL)-12, interferon (IFN)- $\gamma$, tumor necrosis factor (TNF)- $\alpha, I L-17, I L-10$ and transforming growth factor (TGF)- $\beta$ and the production of nitric oxide (NO) in the spleen of mice infected with Leishmania chagasi. It also aimed to evaluate any correlations between $m R N A$ expression TLR 2 and 4 and cytokines and NO production. Infection resulted in increased TLR2-4, IL-17, TNF- $\alpha$ and TGF- $\beta$ mRNA expression during early infection, with decreased expression during late infection correlating with parasite load. IFN- $\gamma$ and IL-12 mRNA expression decreased at the peak of parasitism. IL-10 $\mathrm{mRNA}$ expression increased throughout the entire time period analysed. Although TGF- $\beta, T N F-\alpha$ and IL-17 were highly produced during the initial phase of infection, IFN- $\gamma$ and IL-12 exhibited high production during the final phase of infection. IL-10 and NO showed increased production throughout the evaluated time period. In the acute phase of infection, there was a positive correlation between TLR2-4, TNF- $\alpha$, $I L-17, N O, I L-10$ and TGF- $\beta$ expression and parasite load. During the chronic phase of infection, there was a positive correlation between TLR2-4, TNF- $\alpha, I L-17$ and TGF- $\beta$ expression and parasite load. Our data suggest that infection by L. chagasi resulted in modulation of TLRs 2 and 4 and cytokines.
\end{abstract}

Key words: Leishmania chagasi - cytokines - TLR2 - TLR4

Leishmaniasis remains a serious public health problem. It is endemic in 88 countries and affects 12 million people worldwide. The visceral form, caused by Leishmania donovani and Leishmania chagasi, is prevalent in tropical and subtropical regions, with $90 \%$ of cases occurring in Bangladesh, Brazil, India, Nepal and Sudan (Desjeux 2001, Goto \& Prianti 2009, Verma et al. 2010). Leishmania infection may be asymptomatic, oligosymptomatic or progressive and the most severe cases result in splenomegalia, fever, pancytopenia, hypergammaglobulinemia and weight loss (Badaro et al. 1986). During active visceral leishmaniasis, parasites replicate within mononuclear phagocytes in the spleen, liver and bone marrow; disease can be fatal if the infection is not treated (Goto \& Prianti 2009).

Protective immunity is associated with efficient cellular responses and the production of cytokines such as interleukin (IL)-12, interferon (IFN)- $\gamma$ and tumor necrosis factor (TNF)- $\alpha$ (Pinelli et al. 1995, Dye 1996). Initially, after promastigote phagocytosis, dendritic cells and macrophages release IL-12, which stimulates natural killer (NK) cells to secrete large amounts of IFN- $\gamma$. IL12 induces the differentiation and proliferation of $\mathrm{CD}^{+}$

+ Corresponding author: gagcezario@gmail.com

Received 24 January 2011

Accepted 24 May 2011
Th1 cells populations, which produce more IFN- $\gamma$ (Cunningham 2002). IFN- $\gamma$ is responsible for activating macrophages to produce TNF- $\alpha$, which, in synergism with IFN- $\gamma$, increases phagocytosis and induces macrophage leishmanicidal activity through the production of nitrogen and oxygen metabolites (Belosevic et al. 1989, Bodgan et al. 1990, Liew et al. 1990, Theodos et al. 1991, Ray et al. 2000, Wilhelm et al. 2001, Cunningham 2002). On the other hand, susceptibility to leishmaniasis is associated with a Th2 type immune response, characterised by the predominance of the humoral response and the production of cytokines, such as IL-4 and IL-10 (Agnello et al. 2003, Sharma \& Singh 2009). Immunoregulatory mechanisms, which favour pathogen resistance, immunopathologic control and the establishment of chronic infection, occur when another population of cells, referred to as Tregs, is activated. Tregs produce immunosuppressive cytokines, such as IL-10 and transforming growth factor (TGF)- $\beta$, and are responsible for regulating Th1 and Th2 responses (Belkaid et al. 2002, Gantt et al. 2003, Suffia et al. 2006, Nylén et al. 2007, Sharma \& Singh 2009).

At present, the Th1 and Th2 paradigm is being reconsidered following the discovery of a novel lineage of effector $\mathrm{CD}^{+}$Th cells called Th17 cells, which produce IL$17 \mathrm{~A}$ and F, IL-21, IL-22, IL-23, IL-26 and TNF- $\alpha$ (Dong 2008, Guedes et al. 2010). Th17 cells have been associated with the pathogenesis of several autoimmune and inflammatory diseases, such as psoriasis, rheumatoid arthritis, colitis and toxoplasmosis (Tesmer et al. 2008, Guedes et al. 2010). However, only a few studies have assessed the role 
of IL-17 in protozoan infection and it is not known whether this cytokine acts to aid host defence or contributes to the pathogenesis of these infections (Bacellar et al. 2009).

The specific detection of microorganisms by innate immune cells is mediated by pattern recognition receptors (PRRs), germ line-encoded receptors that conserved microbial structures referred to as pathogen-associated molecular patterns (Medzhitov 2007). Toll-like receptors (TLRs) are essential PRRs that mediate the recognition of microbial structures and induce inflammatory and adaptive responses (Tuon et al. 2008). Several studies have shown the recognition of Leishmania-derived molecules by different TLRs (Becker et al. 2003, de Veer et al. 2003, Flandin et al. 2006). For instance, lipophosphoglycan (LPG) from Leishmania major stimulated macrophages to secrete cytokines such as IL-12 and TNF- $\alpha$ by binding to TLR2 (de Veer et al. 2003). Additionally, IFN- $\gamma$ stimulation of macrophages induced expression of TLR2 and 3 that participated in the recognition of $L$. donovani promastigotes. Additionally, the involvement of TLRs in nitric oxide (NO) induction and TNF- $\alpha$ production has been reported (Flandin et al. 2006). Similarly, in in vivo experiments with mice, Kropf et al. (2004) observed the involvement of TLR4 in the control of L. major infection through increased inducible NO synthase expression.

In view of these observations and in the absence of information concerning experimental visceral leishmaniasis infection, studies evaluating the association between TLRs and Th1, Th2 and Th17 cytokines during L. chagasi infection may contribute to a better understanding of the parasite/host relationship during infection. This study evaluated the mRNA expression of TLRs 2 and 4, the expression and production of IL-12, IFN- $\gamma$, TNF- $\alpha$, IL-17, IL-10 and TGF- $\beta$ and the production of NO. Further, any correlations between RNAm expression of TLRs 2 and 4 , cytokines and NO production and parasite load during infection with $L$. chagasi were evaluated.

\section{MATERIALS AND METHODS}

Animals, parasites and experimental infection - Female Balb/c mice aged 8-10 weeks were obtained from the breeding colony of the Tropical Disease Department, Botucatu Medical School, São Paulo State University (UNESP). All animals received sterile water and food ad libitum throughout the experiment. All of the procedures involving animals and their care were conducted in conformity with National and International Guidelines and were approved by the Ethical Committee for Animal Experimentation of the Botucatu Medical School, UNESP. The mice were divided into two groups: non-infected (G1) and infected with L. chagasi (G2). The animals in G2 were infected intravenously with L. chagasi strain M6445 amastigotes at a concentration of $1 \times 0^{7}$ amastigotes $/ \mathrm{mL}$ in a final volume of $0.1 \mathrm{~mL}$ per animal. Time points for animal euthanasia were previously determined based on approximated parasite load; parasite loads were estimated by the microtitration technique in culture and the imprinting technique in the spleen. Five animals from each group were euthanized on days one ( $24 \mathrm{~h}$ after infection, beginning of the acute phase), three, seven, 14, 21, 28 (parasitism peak), 35 (ini- tial decrease in parasite burden, beginning of the chronic phase) and 42 post-infection (p.i.). Tissue samples from the spleen were immediately obtained after animal death and stored in the RNA stabilisation reagent RNAlater ${ }^{\circledR}$ solution (Applied Biosystems, Foster City, CA, USA) at $80^{\circ} \mathrm{C}$ until RNA extraction for cytokine and TLR expression analysis by real-time polymerase chain reaction (PCR). Other samples from the spleen were snap frozen in liquid nitrogen and stored at $80^{\circ} \mathrm{C}$ until analysis for protein production. Spleen fragments were collected, weighed and then homogenised with a tissue titrate in Schneider's drosophila medium (Gibco BRL, Eragny, FRA) to determine the parasite load.

Cytokine quantification enzyme-linked immunosorbent assay (ELISA) - Snap-frozen spleen samples were lysed in phosphate-buffered saline $(50 \mathrm{mg} / \mathrm{mL})$ with a protease inhibitor cocktail (Complete, EDTA-free, Roche Diagnostics). The tissue fragments were macerated and centrifuged and the supernatants were collected for cytokine quantification. ELISA kits for IL-17, IL-10, IFN- $\gamma$, TNF- $\alpha$, IL-12 and TGF- $\beta$ (R\&D Systems, Minneapolis, MN, USA) were utilised and the procedures were performed according to the manufacturer's instructions. Optical densities were measured at $450 \mathrm{~nm}$. The results are expressed as $\mathrm{pg} / \mathrm{mL}$. The limits of sensitivity for the different assays were as follows: IL-17, IL-10, TGF- $\beta$ and TNF- $\alpha, 15 \mathrm{pg} /$ $\mathrm{mL}$; IFN- $\gamma, 50 \mathrm{pg} / \mathrm{mL}$; and IL-12, $5 \mathrm{pg} / \mathrm{mL}$.

Quantification of cytokines and TLRs 2 and $4 \mathrm{mRNA}$ expression by real-time PCR assay - Total RNA was extracted from spleen tissue samples stored in RNAlater (Applied Biosystems, CA, USA) using the TRIzol reagent (Invitrogen, Carlsbad, CA, Canada) according to the manufacturer's instructions. cDNA was synthesised using $1 \mu \mathrm{g}$ of total RNA as a template in a reverse transcription reaction (ImProm-II ${ }^{\mathrm{TM}}$ Reverse Transcriptase System, Promega, Madison, WI, USA). Quantitative real-time PCR mRNA analyses were performed using the ABI Prism 7300 SDS software (Applied Biosystems, Foster City, CA, USA); Applied Biosystems Power Sybr ${ }^{\circledR}$ Green (Fermentas, Vilnius, LTU) was used for the quantification of amplicons. The standard PCR conditions were as follows: $95^{\circ} \mathrm{C}(10 \mathrm{~min}), 40$ cycles of $95^{\circ} \mathrm{C}$ $(15 \mathrm{~s})$ and $60^{\circ} \mathrm{C}(1 \mathrm{~min})$, followed by a standard denaturation curve. mRNA expression levels of the relevant genes and $\beta$-actin were determined using relative quantification by comparison with a standard curve for each gene, which was included in each PCR run generated from the serial dilution of a cDNA pool from the spleen tissue samples in the study. Standard curves and samples were measured in duplicate and a NO template control was included in all runs. Quantitative real-time PCR mRNA analyses were performed using murine primer sequences available in the GenBank database (Table I).

Parasite load - Parasite load was determined by the microtitration technique in culture. Spleen fragments were weighed and then macerated with a tissue titrate in $4 \mathrm{~mL}$ of Schneider's drosophila medium (Gibco BRL, Eragny, FRA) supplemented with $20 \%$ heat-inactivated foetal calf serum (FCS) (Vitrocell, Campinas, SP, BRA) penicillin $(100 \mathrm{U} / \mathrm{mL})$ and streptomycin $(50 \mathrm{mg} / \mathrm{mL})$ 
TABLE I

Primers used in real-time polymerase chain reaction

\begin{tabular}{|c|c|c|}
\hline Gene & Primers & Sequence \\
\hline IL-2p40 & $\begin{array}{l}\mathrm{F} 1 \\
\mathrm{R} 2\end{array}$ & $\begin{array}{c}\text { 5'-CCC AAG CAG GCC ACA GAA TTG AAA-3' } \\
5^{\prime} \text {-AGT CAA ATC CAG AAC ATG CCG CAG-3' }\end{array}$ \\
\hline IL-17 & $\begin{array}{l}\mathrm{F} 1 \\
\mathrm{R} 2\end{array}$ & $\begin{array}{c}\text { 5'-ACC GCA ATG AAG ACC CTG AT-3' }^{\prime} \text {-' } \\
\text { 5'-TC CTC CGC ATT GAC ACA-3' }\end{array}$ \\
\hline IL-10 & $\begin{array}{l}\text { F1 } \\
\text { R2 }\end{array}$ & $\begin{array}{l}\text { 5'-GCC AAG CCT TAT CGG AAA TG-3' } \\
\text { 5'-CAC CCA GGG AAT TCA AAT GC-3' }\end{array}$ \\
\hline IFN- $\gamma$ & $\begin{array}{l}\mathrm{F} 1 \\
\mathrm{R} 2\end{array}$ & $\begin{array}{l}\text { 5'-AGA GGA TGG TTT GCA TCT GGG TCA-3' } \\
\text { 5'-ACA ACG CTA TGC AGC TTG TTC GTG-3' }\end{array}$ \\
\hline TNF- $\alpha$ & $\begin{array}{l}\text { F1 } \\
\text { R2 }\end{array}$ & $\begin{array}{c}\text { 5'-CAT CTT CTC AAA ATT CGA GTG ACA A-3' } \\
\text { 5'-TGG GAG TAG ACA AGG TAC AAC CC-3' }\end{array}$ \\
\hline TGF- $\beta$ & $\begin{array}{l}\mathrm{F} 1 \\
\mathrm{R} 2\end{array}$ & $\begin{array}{l}\text { 5'-AAC AAT TCC TGG CGT TAC CTT-3' } \\
\text { 5'-CTG CCG TAC AAC TCC AGT GA -3' }\end{array}$ \\
\hline TLR-2 & $\begin{array}{l}\text { F1 } \\
\text { R2 }\end{array}$ & $\begin{array}{c}\text { 5'-TGT CTC CAC AAG CGG GAC TT -3' } \\
\text { 5'-TTC GAT GGA ATC GAT GAT GTT G -3' }\end{array}$ \\
\hline TLR-4 & $\begin{array}{l}\text { F1 } \\
\text { R2 }\end{array}$ & $\begin{array}{c}\text { 5'-TGA CAG GAA ACC CTA TCC AGA GTT-3' } \\
\text { 5'-TCT CCA CAG CCA CCA GAT TCT-3' }\end{array}$ \\
\hline$\beta$-actina & $\begin{array}{l}\text { F1 } \\
\text { R2 }\end{array}$ & 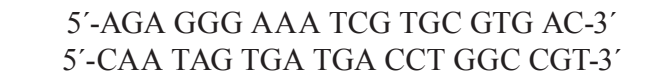 \\
\hline
\end{tabular}

F1: foward; IFN: interferon; IL: interleukin; R2: reverse; TGF: transforming growth factor; TLR: toll-like receptor; TNF: tumor necrosis factor.

(bioMérieux, Marcy-l'Etoile, Rhone, FRA). Under sterile conditions, 96-well microtitration plates (Nunc, Life Tech Inc, Maryland, MA, USA) with $225 \mu \mathrm{L}$ of culture medium per well were plated with four-fold serial dilutions of the homogenized tissue suspension. Plates were incubated for seven days at $26-28^{\circ} \mathrm{C}$ in a $5 \% \mathrm{CO}_{2}$ atmosphere before being examined using an inverted microscope at 100X or 200X magnification (Nikon Eclipse TS100-F, Shanghai, CHI). A titration result was considered positive with the presence of at least one parasite in the last dilution, which was used for parasite load quantification as described by Buffet et al. (1995).

Macrophage culture - After spleen removal, splenic macrophages were obtained according to protocol described in Fenech et al. (1991). Briefly, spleen fragments were removed and placed into Petri dishes $(20$ x $100 \mathrm{~mm})$ containing $5 \mathrm{~mL}$ of Roswell Park Memorial Institute medium (RPMI) 1640 culture medium (Sigma-Aldrich, St. Louis, MO, USA). Fragments were broken up using sterile needles to obtain single cell suspensions. Cell suspensions were then centrifuged at 1,500 rpm for $10 \mathrm{~min}$. Next, the supernatants were discarded and the cell button was taken off by homogenisation. After adding $7 \mathrm{~mL}$ of complete tissue-culture medium (CTCM), consisting of RPMI 1640 tissue culture medium supplemented with $2 \mathrm{mM}$ L-glutamine (Sigma-Aldrich St. Louis, MO, USA), 10\% heat-inactivated FCS (Vitrocell, Campinas, SP, BRA), $20 \mathrm{mM}$ Hepes (Sigma-Aldrich, St. Louis, $\mathrm{MO}, \mathrm{USA}$ ) and $40 \mathrm{ug} / \mathrm{mL}$ gentamicin (Gibco Laboratories, Grand Island, NY), macrophages were counted using neutral red $(0.02 \%)$ and the concentrations were adjusted. Next, $100 \mu \mathrm{L}$ of the suspensions, containing
$1 \times 10^{6}$ cells $/ \mathrm{mL}$, were dispensed in each well of a 96well flat-bottomed plate (Nunc, Life Tech Inc, Maryland, MA, USA). After incubation in $5 \% \mathrm{CO}_{2}$ at $37^{\circ} \mathrm{C}$ for $2 \mathrm{~h}$, non-adhering cells were aspirated and each well was rinsed twice with CTCM. Macrophages were then cultured in $\mathrm{CTCM}$ in $5 \% \mathrm{CO}_{2}$ at $37^{\circ} \mathrm{C}$ for $24 \mathrm{~h}$; supernatants were then collected and assayed for NO production.

Determination of nitrite $\left(\mathrm{NO}_{2}^{-}\right)$production - NO production was quantified by the accumulation of $\mathrm{NO}_{2}^{-}$in the supernatants using the standard Griess assay (Green et al. 1982). Briefly, $100 \mu \mathrm{L}$ of supernatants from the macrophage cultures were mixed with an equal volume of the Griess Reagent (Sigma-Aldrich, St. Louis, MO, USA), containing $1 \%$ sulfanilamide (Sigma-Aldrich, St. Louis MO, USA) diluted in $5 \% \mathrm{H}_{3} \mathrm{PO}_{4}$ and $0.1 \%$ N-(1 Naphthyl) ethyl-enediamine (Sigma-Aldrich Co, USA). Absorbance at $540 \mathrm{~nm}$ was determined using an automated ELISA plate reader (MD 5000, Dynatech Laboratories Inc, Chantilly, VA, USA). Conversion of absorbance to micromolar concentrations of NO was performed using a standard curve of a known concentration of $\mathrm{NaNO}_{2}$ diluted in distilled $\mathrm{H}_{2} \mathrm{O}$. All measurements were performed in triplicate and are expressed in micromolar concentrations of NO.

Statistical analysis - Results were statistically analysed by ANOVA using Graphpad Software (Graph Pad Instat 3.05, San Diego, CA, USA) and compared utilising the Tukey-Kramer test. Spearman analysis was performed for the correlation analysis between the expression of TLR2-4, IL-12, IFN- $\gamma$, TNF- $\alpha$, TGF- $\beta$, IL-10, IL-17, NO and parasite load. Significance was set at $\mathrm{p}<0.05$. 


\section{RESULTS}

Parasite load in L. chagasi-infected Balb/c mice - The parasite load increased only slightly until day seven p.i., with a greater increase observed on day 14 p.i.; splenic parasite load peaked at day 28 p.i. and decreased from day 35 p.i. (Fig. 1).

L. chagasi-induced TLR2 and 4 mRNA expression To determine whether $L$. chagasi infection affected the expression of TLRs 2 and 4, mRNA levels were evaluated. L. chagasi-infected animals in G2 exhibited greater TLR4 mRNA expression at all of the studied time points compared to the non-infected animals in G1. TLR4 mRNA expression in G2 animals was significantly higher on days one, three, seven, 14, 21 and 28 p.i., compared with days 35 and 42 p.i. (Fig. 2A). The animals in G2 also showed higher mRNA expression of TLR2 in relation to G1 animals at all studied time points. In G2 animals, TLR 2 mRNA expression was significantly higher on days 14, 21 and 28 p.i. It was also observed that, at the beginning of infection (days 1, 3 and 7), TLR2 mRNA expression was higher than the expression observed on days 35 and 42 p.i. (Fig. 2B).

Proinflammatory and Th17 cytokines $m R N A$ and protein expression during L.chagasi infection - As IFN- $\gamma$ and IL-12 are considered to be the major protective cytokines in visceral leishmaniasis and TNF- $\alpha$ and IL-17 have been shown to be inflammatory in several parasitic infections, we investigated the expression of these cytokines throughout the course of L. chagasi infection. In G2 animals, higher levels of IFN- $\gamma$ mRNA expression were detected, compared with those in G1 animals from days three-14 p.i. and end of the time period (35th and 42th days); production in $\mathrm{G} 2$ was similar at the beginning, lower from the 14-28th days and higher at the end of infection (35th and 42th days) compared to levels observed in G1 mice. The highest IFN- $\gamma$ production occurred on the 42th day p.i. (Fig. 3A, B). With respect to IL-12, IL-12 mRNA expression was significantly higher in $\mathrm{G} 2$ animals compared to G1 animals throughout the period of infection evaluated. In G2 animals, IL-12 mRNA expression increased from day one-21 p.i., with decreased levels observed on day 28 p.i. IL-12 mRNA expression was significantly higher on days 14 and 21 in G2 animals compared to expression levels on other days. IL-12 mRNA was also significantly increased on days 28,35 and 42 compared to levels during the beginning of infection on days one and three p.i. IL-12 protein production in G2 animals was significantly lower on days seven, 14,21 and 28 p.i. and higher on days 35 and 42 p.i. compared to IL-12 levels detected in G1 animals. In G2 animals, the increased IL-12 production during late infection (days 35 and 42 p.i.) was statistically significant when compared to the IL-12 levels detected on days seven, 14, 21 and 28 p.i. $(\mathrm{p}<0.001)($ Fig. $3 \mathrm{~A}, \mathrm{~B})$

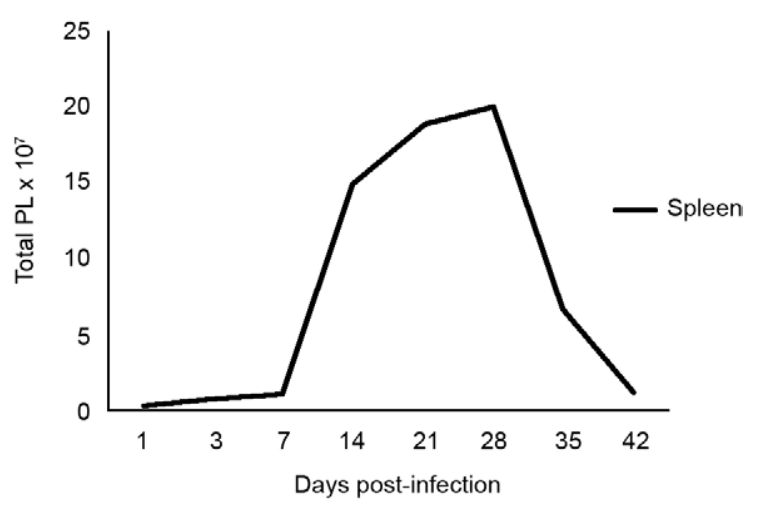

Fig. 1: total parasite load (PL) in the spleen of Balb/c mice during the course of visceral infection with Leishmania chagasi. The data means are representative of two independent experiments (5 mice per group).
A

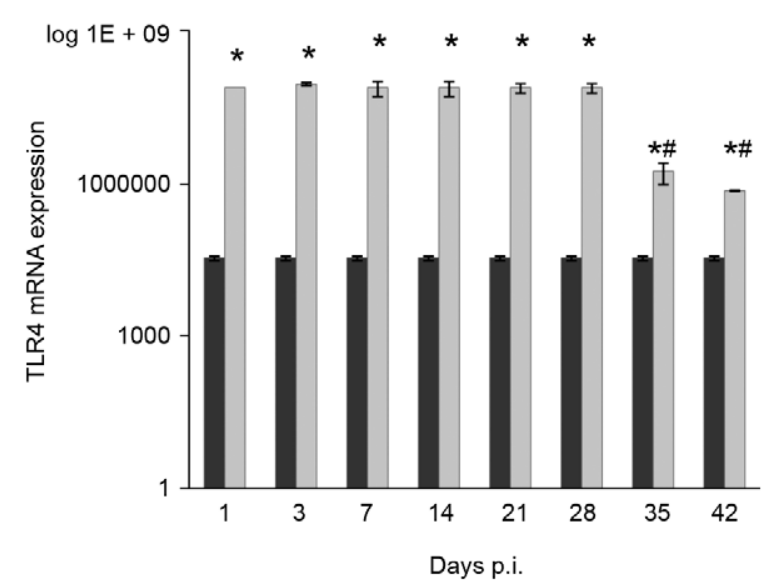

B

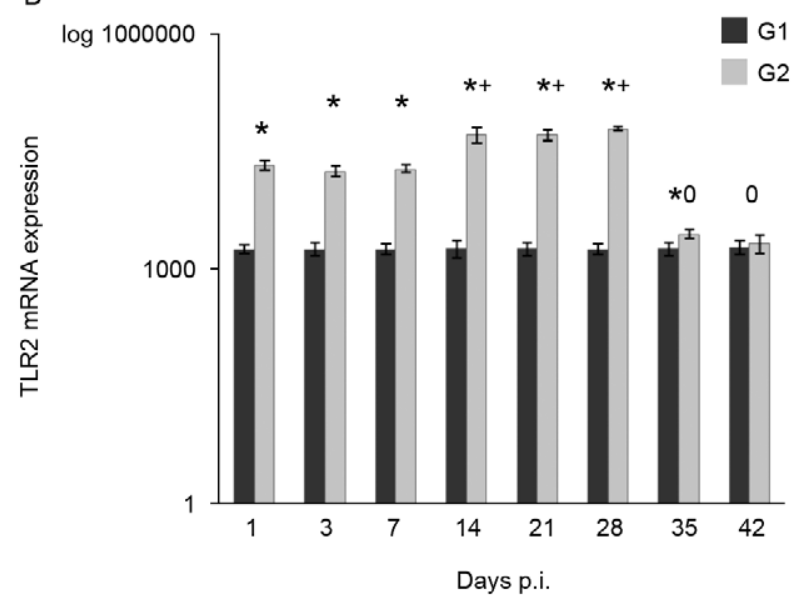

Fig. 2: mRNA expression of Toll-like receptors (TLR)2 and 4 during Leishmania chagasi infection. TLR2 and 4 were quantified in the splenocytes of infected (G2) and non-infected (G1) Balb/c mice by real-time polymerase chain reaction on day one, three, seven, 14, 21, 28, 35 and 42 post-infection (p.i.). The data (mean \pm standard error of the mean) are representative of two independent experiments ( 5 mice per group). Statistically significance between groups is indicated. *: $p<0.05$ vs. G1; \#: $p<0.05$ vs. G2 one-28 p.i.; 0: p $<0.05$ vs. G2 one-28 p.i.; +: p $<0.05$ vs. G2 one-seven p.i., 35 and 42 days p.i. 
Increased TNF- $\alpha$ and IL-17 mRNA expression and protein were detected in G2 animals compared to G1 animals throughout the entire course of infection beginning at day three p.i. In G2 animals, TNF- $\alpha$ mRNA levels increased until day 14 p.i. and then remained steady until 28 days p.i. IL-17 mRNA expression and protein production steadily increased in G2 animals until day 28 p.i.; decreased expression was observed on days 35 and 42 p.i. (Fig. 4A, B). There was an inverse correlation between parasite load and IFN- $\gamma$ and IL-12 $(r=-0.22$ to $-0.87, \mathrm{p}<0.05)$ production and a direct correlation between parasite load and IL-17 and TNF- $\alpha(\mathrm{r}=0.26-0.77$, $\mathrm{p}<0.05)$ expression and production during infection.

TGF- $\beta$ and IL-10 mRNA expression and production during L. chagasi infection - As TGF- $\beta$ and IL-10 have been demonstrated to contribute to the control of inflammatory processes and parasite persistence, we evaluated their mRNA expression and production during $L$. chagasi infection. The animals in G2 showed higher TGF- $\beta$ mRNA expression and protein levels compared with those in G1 animals, throughout the course of infection beginning at day three p.i.; however, levels in G2 animals decreased on days 35 and 42 p.i. Similar to TGF- $\beta$, IL-10 mRNA expression and protein production in G2 animals were higher throughout the course of infection starting at day three p.i. compared with those in G1 animals. Interestingly, IL-10 mRNA expression and protein levels increased steadily throughout all of the measure time points compared with those in G1. In G2 animals, the highest IL-10 protein levels were observed on days 35 and 42 p.i. (Fig. 5A, B).

During the initial phase of infection, there was a direct correlation between IL-10 and TGF- $\beta$ mRNA expression and protein production and IL-17, TNF- $\alpha$, NO production and parasite load $(\mathrm{r}=0.32-0.53, \mathrm{p}<0.05)$. Additionally, there was an inverse correlation between IL-10 and TGF- $\beta$ mRNA expression and protein production and IL-12 and IFN- $\gamma$ protein levels $(r=-0.16$ to $-0.56, p<0.05)$. Late in infection, there was a direct correlation between IL-10 mRNA expression and protein levels and IL-12, IFN- $\gamma$ and NO production $(\mathrm{r}=0.24-0.89, \mathrm{p}<0.05)$.
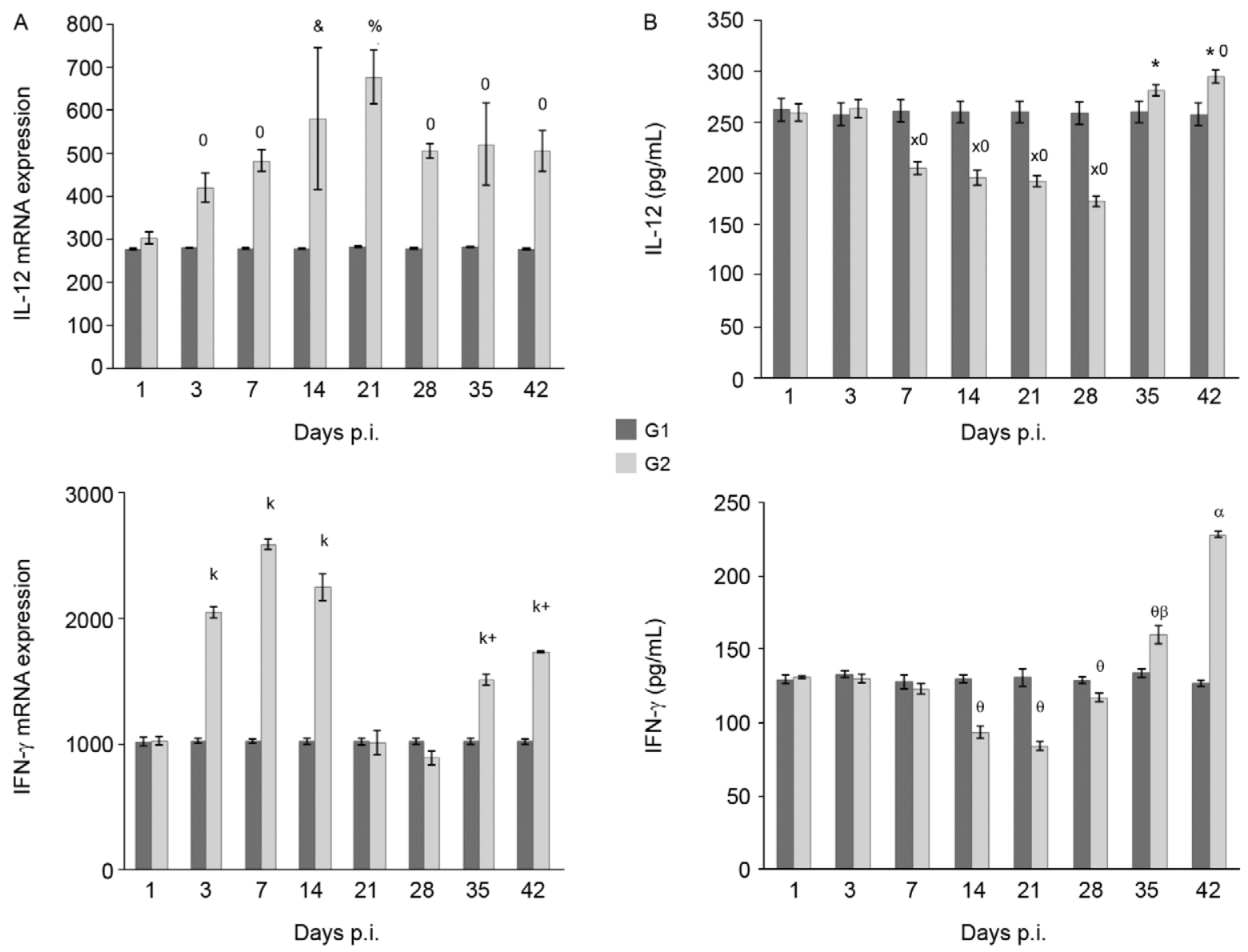

Fig. 3: interferon (IFN)- $\gamma$ and interleukin (IL)-12 mRNA expression and production during Leishmania chagasi infection. IFN- $\gamma$ and IL-12 were quantified in the splenocytes of infected (G2) and non-infected (G1) Balb/c mice by real-time polymerase chain reaction (A) and enzyme-linked immunosorbent assay (B) on days one, three, seven, 14, 21, 28, 35 and 42 post-infection (p.i.). The data (mean \pm standard error of the mean) are representative of two independent experiments ( 5 mice per group). Statistically significance between groups is indicated. $\mathrm{k}$ : $\mathrm{p}<0.001 \mathrm{vs.} \mathrm{G1}$ and G2 one, 21, 28 p.i.; +: $p<0.001$ vs. G2 three, seven, 14 p.i.; $\theta$ : $p<0.01$ vs. G1; $\beta$ : $p<0.05$ vs. G2 14-28 p.i.; $\alpha$ : p $<0.001$ vs. G1 and G2 one-35 p.i.; $0: \mathrm{p}<0.05$ vs. $\mathrm{G} 1$ and $\mathrm{G} 2 ; \&$ : $\mathrm{p}<0.01$ vs. G2; \%: p $<0.001$ vs. G2 one p.i.; $\mathrm{x}: \mathrm{p}<0.001$ vs. G2 one, three p.i.; *: p $<0.001$ vs. G2 seven-28 p.i. 
$\mathrm{NO}_{2}^{-}$production during L. chagasi infection - NO production by splenic cells during $L$. chagasi infection is depicted in Fig. 6. NO production by splenic cells from G2 animals was significantly higher compared to cells from $\mathrm{G} 1$ animals beginning on the 14 day p.i. In G2 animals, NO levels were maintained at steady levels until the seven day p.i. However, beginning on the 14th day, NO levels increased continually until the end of the experiment. During the initial phase of infection, there was a positive correlation between NO levels and IL-17, TNF- $\alpha$, IL-10 and TGF- $\beta$ production and parasite load $(r=0.23$ $0.76, p<0.05$ ). Late in infection, a positive correlation was observed between NO levels and IL-12, IFN- $\gamma$ and IL-10 production $(\mathrm{r}=0.13-0.86, \mathrm{p}<0.05)$. Additionally, an inverse correlation between NO levels and parasite load $(r=$ $-0.65, \mathrm{p}<0.05$ ) was observed during late infection.

Correlation between the expression of TLR2-4 mRNA and the production of cytokines and NO and parasite load during L. chagasi infection - The results of the correlation analysis between the levels of expression of
TLR2-4 and the production of cytokines and NO and parasite load are shown in Tables II and III. A positive correlation was observed between TLR2-4 and TNF- $\alpha$, IL-17, IL-10, TGF- $\beta$ and parasite load at the beginning of infection and between TLR2-4, TNF- $\alpha$, IL-17, TGF- $\beta$ and parasite load late in infection. Additionally, an inverse correlation was found between TLR2-4, IL-12, IFN- $\gamma$ and parasite load at the beginning of infection and between TLR2-4 and IL-12, IFN- $\gamma$, NO, IL-10 at the end of infection (Tables II, III).

\section{DISCUSSION}

Although studies have suggested an involvement of TLRs in the initial interaction of Leishmania with the immune system, the role played by TLRs in visceral leishmaniasis is still unclear. In this context, we aimed to evaluate the expression of TLR2 and 4, the expression and production of IFN- $\gamma$, TNF- $\alpha$, IL-17, IL-10 and TGF- $\beta$ and the production of NO during the acute and chronic phases of L. chagasi infection in Balb/c mice.
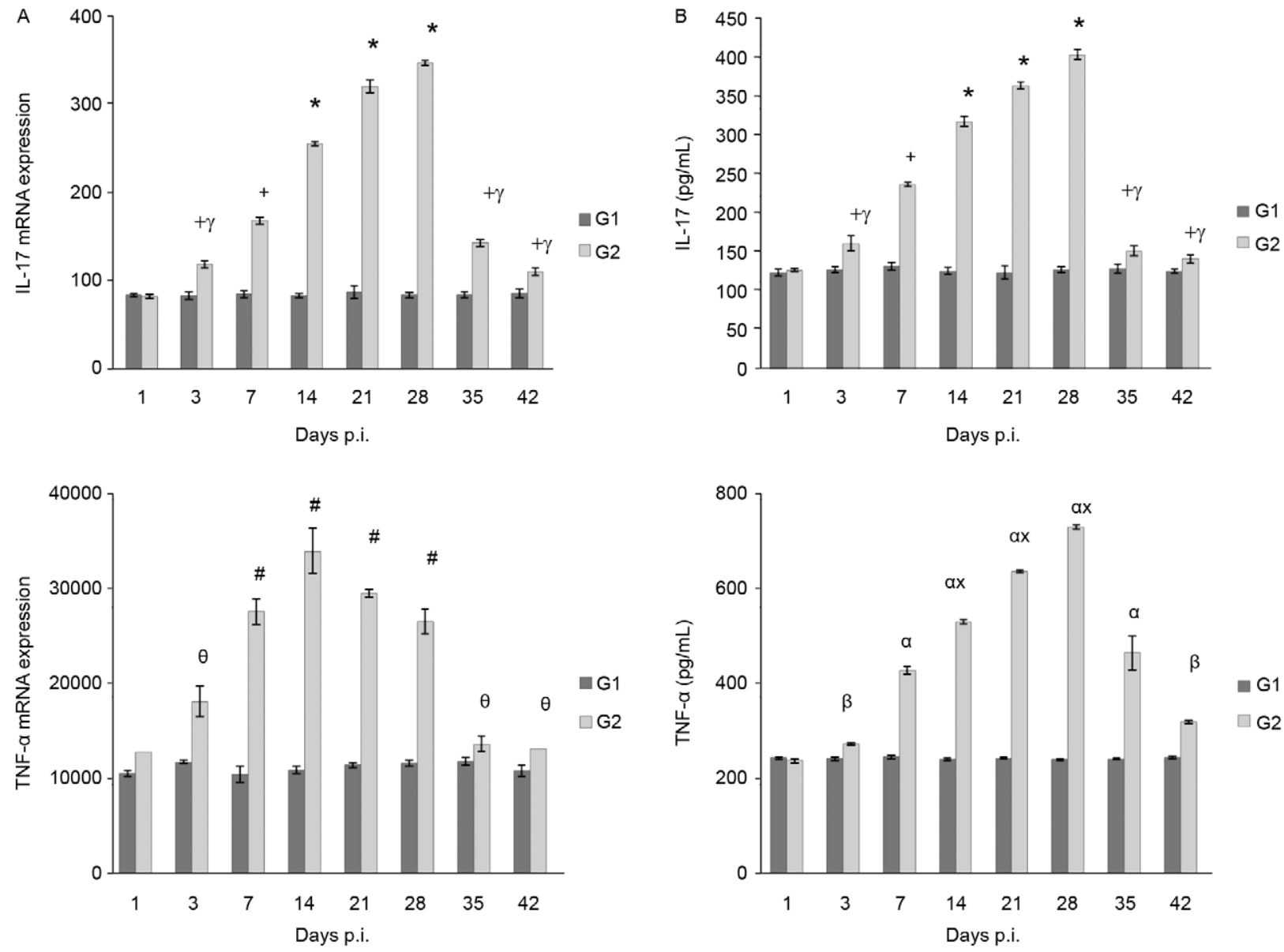

Fig. 4: tumor necrosis factor (TNF)- $\alpha$ and interleukin (IL)-17 mRNA expression and production during Leishmania chagasi infection. TNF- $\alpha$ and IL-17 were quantified in the splenocytes of infected (G2) and non-infected (G1) Balb/c mice by real-time polymerase chain reaction (A) and enzyme-linked immunosorbent assay (B) on days one, three, seven, 14, 21, 28, 35 and 42 post-infection (p.i.). The data (mean \pm standard error of the mean) are representative of two independent experiments (5 mice per group). Statistically significance between groups is indicated. $*: \mathrm{p}$ $<0.001$ vs. G1 and G2 one, three, seven, 35,42 p.i.; +: p $<0.05$ vs. G1 and $G 2$ one p.i.; $\gamma: p<0.05$ vs. G2 seven-28 p.i.; $\theta$ : p $<0.01$ vs. G1 and G2 seven-28 p.i.; \#: $p<0.01$ vs. G1 and G2 one, three, 35, 42 p.i. $\beta$ : $p<0.05$ vs. G1 and G2 seven, 35 p.i.; $\alpha$ : $p<0.001$ vs. G1 and G2 one, three, 42 p.i.; $\mathrm{x}: \mathrm{p}<0.01$ vs. G2 seven, 35 p.i. 
Additionally, we correlated the expression of TLR2-4, cytokine production and $\mathrm{NO}$ production with parasite load. L. chagasi infection induced TLR 2 and 4 mRNA expressions throughout the course of infection, indicating that these receptors could potentially be involved in parasite recognition. These results are in agreement with previous studies showing that Leishmania parasites can bind to both TLR2 and 4 to enter host cells (Kropf et al. 2004, Flandin et al. 2006). We also found that, at the peak of parasitism, there was higher expression of TLR4 and particularly of TLR2. A possible explanation for this result is that the parasite and/or cytokines can modulate the expression of these receptors. This idea is supported by studies showing that LPG from L. major is recognised by TLR 2 in NK cells, which leads to their activation and a subsequent increase in surface TLR2 levels (Becker et al. 2003). However, based on our experiments, it cannot be stated that increased TLR2 and 4 mRNA expression was due to increased mRNA levels within individual cells. In our study, increased expression may have occurred as a result of the influx of inflammatory cells to the spleen, particularly at the beginning of infection. Additionally, the decrease in parasite load observed in the chronic phase of infection may be associated with the partial control of the infection. Although microscopy was not performed to detect whether an alteration in the number of cells occurred, it can be suggested that the decreased parasite load late in infection may also be related to a reduction in cell infiltrates. Hence, it can be suggested that the lower expression of TLRs at the end of infection may have resulted from a decreased number of parasites stimulating the cells, as well as from a smaller influx of cells into the spleen.

We hypothesise that $L$. chagasi infection resulted in cytokine modulation. The mechanism responsible for cytokine production most likely involves TLRs. Parasite components could have led to the activation of TLR2 and 4 , resulting in the production of cytokines (Tuon et al. 2008). Although the mRNA expression of IL-12 and IFN- $\gamma$ was higher in the infected animals, production during the initial phase of infection remained low and was reduced in comparison to G1 animals. These findings can be explained by the fact that the process of translation of these cytokines was prevented (Maier et al. 2009). The inhibition of cytokine synthesis may have occurred due to the action of suppressive mechanisms, such as soluble factors
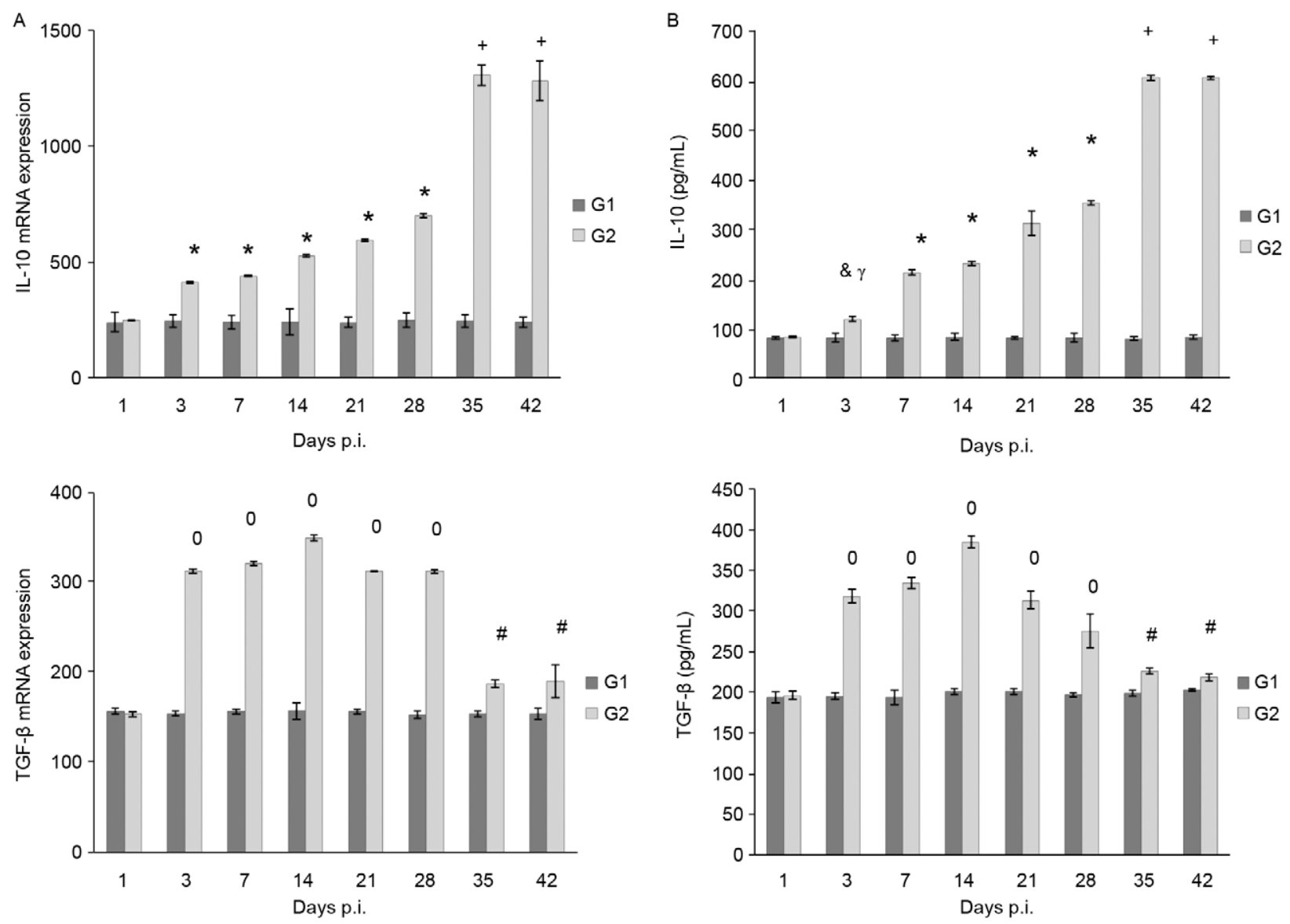

Fig. 5: mRNA expression and production of transforming growth factor (TGF)- $\beta$ and IL-10 during Leishmania chagasi infection. TGF- $\beta$ and interleukin (IL)-10 were quantified in the splenocytes of infected (G2) and non-infected (G1) Balb/c mice by real-time polymerase chain reaction (A) and enzyme-linked immunosorbent assay (B) on days one, three, seven, 14, 21, 28, 35 and 42 post-infection (p.i.). The data (mean \pm standard error of the mean) are representative of two independent experiments (5 mice per group). Statistically significance between groups is indicated. *: $\mathrm{p}<0.001$ vs. G1 and G2 one, 35, 42 p.i.; +: $\mathrm{p}<0.001$ vs. G1 and G2 one-28 p.i.; \&: p $<0.05$ vs. G1 and G2 one p.i.; $\gamma: \mathrm{p}<0.01$ vs. G2 seven- 28 p.i.; 0: $p<0.001$ vs. G1 and G2 35, 42 p.i.; \#: $p<0.05$ vs. G1 and G2 one p.i. 
or different cell types (Barral et al. 1986, Carvalho et al. 1989, Bacellar et al. 1996). The presence of such mechanisms has been shown in studies using peripheral blood mononuclear cells (PBMC) (Barral et al. 1986, Carvalho et al. 1989, Bacellar et al. 1996). Our results show that low IL-12 and IFN- $\gamma$ production was followed by high parasite load; hence, the high parasite load observed at the beginning and in the intermediate phase of infection

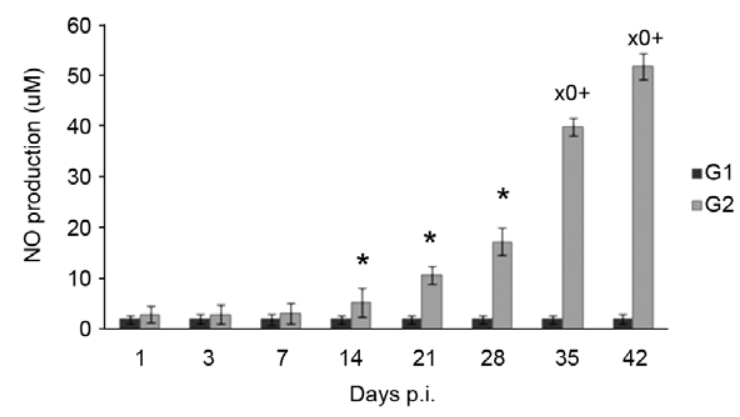

Fig. 6: nitric oxide (NO) production during Leishmania chagasi infection. NO was quantified in the splenic macrophages of infected (G2) and non-infected (G1) Balb/c mice on days one, three, seven, 14, 21, 28,35 and 42 post-infection (p.i.). The data (mean \pm standard error of the mean) are representative of two independent experiments (5 mice per group). Statistically significance between groups is indicated. *: p $<0.05$ vs. G1; x: p $<0.001$ vs. G1; 0: p $<0.001$ vs. G2 one-14 p.i.; +: $\mathrm{p}<0.05$ vs. G2 21,28 p.i. may be due to the low release of these cytokines by cells. Conversely, the decreased parasite load in the chronic phase would be related to the increased production of these cytokines. These results are in agreement with others showing that IL-12 and IFN- $\gamma$ play a protective role during Leishmania infection because they promote the Th1 response in addition to controlling parasitic replication and resolving the infection (Hernandez-Pando et al. 1997, Watford et al. 2004, Cummings et al. 2010). Consistent with our results, several studies have shown low or absent IFN- $\gamma$ or IL-12 production in the supernatants of PBMC cultures stimulated with Leishmania antigen (Cillari et al. 1995, Ghalib et al. 1995, Kumar et al. 2001). Additionally, the modulation of TLR receptors by IFN- $\gamma$ and IL-12 has also been shown. Studies have found that macrophages activated by IFN- $\gamma$ exhibit higher TLR2 expression on their surface (Flo et al. 2001). In an experimental model of neurocysticercosis, increased expression of TLRs 11-13 was observed in the acute phase compared to the chronic phase. Acute infection was associated with the Th1 response. However, a Th1/Th2 response pattern was detected in the chronic phase and was associated with decreased expression of TLRs 11-13, which contributed to the reduction of the tissue damage induced by excessive inflammation (Mishra et al. 2008).

In this study, it was also shown that L. chagasi infection resulted in increased IL-17 mRNA expression and protein production. These results correlated with the profile of TLR2-4 expression and parasite load and showed a response characteristic that was opposite to IFN- $\gamma$ and of

\section{TABLE II}

Correlation (r) between the expression of toll-like receptor (TLR)2 and the production of cytokines and nitric oxide (NO) and parasite load (PL) during Leishmania chagasi infection

\begin{tabular}{|c|c|c|c|c|c|c|c|c|c|}
\hline \multicolumn{10}{|c|}{ TLR2 } \\
\hline & & 1 & 3 & 7 & 14 & 21 & 28 & 35 & 42 \\
\hline \multirow[t]{2}{*}{ IL-12 } & $\mathrm{r}$ & $-0,37$ & $-0,43$ & $-0,89$ & $-0,87$ & $-0,83$ & $-0,53$ & $-0,43$ & $-0,6$ \\
\hline & $\mathrm{p}$ & 0,042 & 0,039 & 0,018 & 0,029 & 0,035 & 0,027 & 0,017 & 0,009 \\
\hline \multirow[t]{2}{*}{ IFN- $\gamma$} & $\mathrm{r}$ & $-0,52$ & $-0,21$ & $-0,58$ & $-0,84$ & $-0,27$ & $-0,96$ & $-0,32$ & $-0,22$ \\
\hline & $\mathrm{p}$ & 0,028 & 0,067 & 0,022 & 0,032 & 0,059 & 0,002 & 0,0053 & 0,0076 \\
\hline \multirow[t]{2}{*}{ TNF- $\alpha$} & $\mathrm{r}$ & $-0,67$ & $-0,39$ & $0,78^{a}$ & $0,81^{a}$ & $0,96^{a}$ & $0,89^{a}$ & $0,63^{a}$ & $0,85^{a}$ \\
\hline & $\mathrm{p}$ & 0,139 & 0,043 & 0,047 & 0,046 & 0,001 & 0,016 & 0,047 & 0,049 \\
\hline \multirow[t]{2}{*}{ IL-17 } & $\mathrm{r}$ & $-0,26$ & $0,82^{a}$ & $0,98^{a}$ & $0,63^{a}$ & $0,79^{a}$ & $0,88^{a}$ & $0,25^{a}$ & $0,1^{a}$ \\
\hline & $\mathrm{p}$ & 0,66 & 0,044 & 0,001 & 0,046 & 0,048 & 0,019 & 0,048 & 0,045 \\
\hline \multirow[t]{2}{*}{ IL-10 } & $\mathrm{r}$ & $-0,49$ & 0,4 & $0,933^{a}$ & $0,8^{a}$ & $0,07^{a}$ & $0,81^{a}$ & $-0,59$ & $-0,54$ \\
\hline & $\mathrm{p}$ & 0,318 & 0,342 & 0,006 & 0,045 & 0,005 & 0,049 & 0,21 & 0,26 \\
\hline \multirow[t]{2}{*}{ TGF- $\beta$} & $\mathrm{r}$ & $-0,02$ & $0,97^{a}$ & $0,26^{a}$ & $0,89^{a}$ & $-0,32$ & $-0,95$ & $0,67^{a}$ & $0,85^{a}$ \\
\hline & $\mathrm{p}$ & 0,955 & 0,009 & 0,049 & 0,017 & 0,05 & 0,002 & 0,013 & 0,016 \\
\hline \multirow[t]{2}{*}{$\mathrm{NO}$} & $\mathrm{r}$ & 0,69 & 0,44 & $0,78^{a}$ & $0,13^{a}$ & $0,93^{a}$ & $0,98^{a}$ & $-0,04$ & $-0,83$ \\
\hline & $\mathrm{p}$ & 0,127 & 0,97 & 0,001 & 0,007 & 0,007 & 0,005 & 0,009 & 0,037 \\
\hline \multirow[t]{2}{*}{ PL } & $\mathrm{r}$ & $-0,27$ & $0,29^{a}$ & $0,37^{a}$ & $0,61^{a}$ & $0,74^{a}$ & $0,56^{a}$ & $0,68^{a}$ & $0,48^{a}$ \\
\hline & $\mathrm{p}$ & 0,042 & 0,4 & 0,027 & 0,008 & 0,03 & 0,005 & 0,037 & 0,025 \\
\hline
\end{tabular}

$a$ : statistically significant differences among expression of TLR 2 and production of cytokine and NO and PL are shown as $\mathrm{p}<0,05$; IFN: interferon; IL: interleukin; TGF: transforming growth factor; TNF: tumor necrosis factor. 
IL-12. It has been observed that TLR4 activation stimulates dendritic cells to produce IL-23, which is important for Th17 cell maintenance (Vanden et al. 2006). Additionally, in a previous study (unpublished observations) using the same infection model, a direct correlation between IL-17, TNF- $\alpha$ and IL- 6 was observed. These cytokines were associated with an intense inflammatory process and tissue damage. Hence, according our findings, we suggest that IL-17 is involved not in infection control, but in pathogenesis mechanisms that contribute to disease development. These results are in agreement with other studies showing that in experimental L. $m a$ jor infection, increased IL-17 production was observed in susceptible Balb/c animals compared to resistant C57BL/6 animals. These studies also showed that lesion development and infection susceptibility were related to IL-17 production. Balb/c mice failed to control lesion exacerbation, exhibiting a larger recruitment of neutrophils to asymptomatic sites, while also exhibiting similar IFN- $\gamma$ and IL-10 production levels (Anderson et al. 2009, Kostka et al. 2009). In regards to TNF- $\alpha$ levels, our results indicate a positive correlation with TLR2-4 expression, IL-17 mRNA expression and protein levels and parasite load. In a study using the SIR2RP protein of Leishmania infantum, it was shown that TNF- $\alpha$ production from bone marrow DCs was dependent on TLR2 (Silvestre et al. 2009). Although TNF- $\alpha$ is essential for normal responses associated with parasite elimination, its excessive or inappropriate production may cause damage to the host (Robak et al. 1998, Bradley 2008). Consistent with this, in a study on visceral leishmaniasis, high
TNF- $\alpha$ concentrations were related to disease progression (Kaye et al. 2004). Additionally, TNF- $\alpha$ inhibition healed ulcers in patients with American cutaneous leishmaniasis (Ribeiro de Jesus et al. 2008). In accordance with these studies, our results also suggest that TNF- $\alpha$ is involved not in protection, but in tissue damage and pathogenesis. NO production increased during infection. Consistent with this, large amounts of $\mathrm{NO}$ were reported in the supernatants of murine macrophages infected with $L$. chagasi and stimulated with IFN- $\gamma$; these results reflects the importance of NO in leishmanicidal activity (Gantt et al. 2001). Our results indicate a positive correlation, in the initial phase of infection, between NO levels and TLR2-4 expression and between IL-17, TNF- $\alpha$, IL-10 and TGF- $\beta$ production and parasite load. During late infection, our results indicate a positive correlation between NO levels and IL-12, IFN- $\gamma$ and IL-10 production. Although the levels of such metabolites were high at the beginning of infection, this increase did not result in parasite destruction during the initial phase of infection. Parasite clearance occurred only at the beginning of the chronic phase, most likely when the levels of NO were sufficiently increased to eliminate the parasites. This was also likely due to the elevated levels of IFN- $\gamma$, the main cytokine involved in the induction of NO.

In leishmaniasis, similar to other infections, IL-10 and TGF- $\beta$ have been identified as important cytokines involved in homeostatic mechanisms and in limiting tissue damage caused by extensive inflammation. Nevertheless, these cytokines also favour pathogen persistence (Belkaid et al. 2001). In visceral leishmaniasis, IL-10 has

TABLE III

Correlation (r) between the expression of toll-like receptor (TLR) 4 and the production of cytokines and nitric oxide (NO) and parasite load (PL) during Leishmania chagasi infection

\begin{tabular}{|c|c|c|c|c|c|c|c|c|c|}
\hline \multicolumn{10}{|c|}{ TLR4 } \\
\hline & & 1 & 3 & 7 & 14 & 21 & 28 & 35 & 42 \\
\hline \multirow[t]{2}{*}{ IL-12 } & $\mathrm{r}$ & $-0,15$ & $-0,73$ & $-0,42$ & $-0,6$ & $-0,73$ & $-0,25$ & $-0,95$ & $-0,99$ \\
\hline & $\mathrm{p}$ & 0,77 & 0,035 & 0,04 & 0,013 & 0,049 & 0,016 & 0,002 & 0,001 \\
\hline \multirow[t]{2}{*}{ IFN- $\gamma$} & $\mathrm{r}$ & $-0,016$ & $-0,87$ & $-0,96$ & $-0,97$ & $-0,86$ & $-0,96$ & $-0,99$ & $-0,52$ \\
\hline & $\mathrm{p}$ & 0,098 & 0,024 & 0,022 & 0,001 & 0,025 & 0,001 & 0,028 & 0,047 \\
\hline \multirow[t]{2}{*}{ TNF- $\alpha$} & $\mathrm{r}$ & 0,2 & 0,76 & $1^{a}$ & $0,95^{a}$ & $0,11^{a}$ & $0,71^{a}$ & $0,66^{a}$ & $0,12^{a}$ \\
\hline & $\mathrm{p}$ & 0,695 & 0,05 & 0,001 & 0,002 & 0,049 & 0,046 & 0,014 & 0,049 \\
\hline \multirow[t]{2}{*}{ IL-17 } & $\mathrm{r}$ & $-0,26$ & $0,78^{a}$ & $0,65^{a}$ & $0,84^{a}$ & $0,78^{a}$ & $0,98^{a}$ & $0,84^{a}$ & $0,77^{a}$ \\
\hline & $\mathrm{p}$ & 0,61 & 0,047 & 0,034 & 0,035 & 0,048 & 0,004 & 0,009 & 0,006 \\
\hline \multirow[t]{2}{*}{ IL-10 } & $\mathrm{r}$ & $-0,85$ & $0,97^{a}$ & $0,78^{a}$ & $0,58^{a}$ & $0,98^{a}$ & $0,95^{a}$ & $-0,88$ & $-0,97$ \\
\hline & $\mathrm{p}$ & 0,029 & 0,009 & 0,006 & 0,022 & 0,003 & 0,003 & 0,019 & 0,007 \\
\hline \multirow[t]{2}{*}{ TGF- $\beta$} & $\mathrm{r}$ & $-0,48$ & $0,49^{a}$ & $0,8^{a}$ & $0,98^{a}$ & $-0,32$ & $-0,95$ & $0,67^{a}$ & $0,32^{a}$ \\
\hline & $\mathrm{p}$ & 0,32 & 0,035 & 0,047 & 0,02 & 0,037 & 0,001 & 0,013 & 0,048 \\
\hline \multirow[t]{2}{*}{ NO } & $\mathrm{r}$ & $-0,96$ & $-0,72$ & $0,1^{a}$ & $0,43^{a}$ & $0,58^{a}$ & $0,88^{a}$ & $-0,98$ & $-0,2$ \\
\hline & $\mathrm{p}$ & 0,001 & 0,102 & 0,001 & 0,038 & 0,022 & 0,02 & 0,006 & 0,0069 \\
\hline \multirow[t]{2}{*}{ PL } & $\mathrm{r}$ & $-0,74$ & $0,61^{a}$ & $0,44^{a}$ & $0,74^{a}$ & $0,27^{a}$ & $0,32^{a}$ & $0,81^{a}$ & $0,64^{a}$ \\
\hline & $\mathrm{p}$ & 0,043 & 0,036 & 0,021 & 0,01 & 0,009 & 0,014 & 0,005 & 0,012 \\
\hline
\end{tabular}

$a$ : statistically significant differences between the expression of TLR4 and the production of cytokines and NO and PL are shown as $\mathrm{p}<0.05$; IFN: interferon; IL: interleukin; TGF: transforming growth factor; TNF: tumor necrosis factor. 
been detected in the serum, lymph nodes and the spleen (Cillari et al. 1995, Ghalib et al. 1995, Kenney et al. 1998, Ansari et al. 2006). These findings are in agreement with our results, which show the presence of high IL-10 levels in the spleen, particularly in late infection. However, our results suggest that, at the beginning of infection, IL-10 levels were associated with TLRs 2 and 4 expressions, NO production and parasite load, in addition to low IFN- $\gamma$ and IL-12 levels. Although this may suggest the involvement of IL-10 in the suppression of these cytokines, this may have not occurred because IFN- $\gamma$, IL-12 and NO levels at the end of infection were high, despite high levels of IL-10. With respect to TGF- $\beta$, results show that, in addition to its involvement in IL-17 induction together with IL-6, it may also be related to the suppression of protective mechanisms, acting directly or indirectly to decrease IFN- $\gamma$ and IL-12 production. In our study, high TGF- $\beta$ levels were detected at the beginning of infection and correlated positively with TLR2-4 expression and parasite load and negatively with IFN- $\gamma$ and IL-12 production; further, the opposite situation was observed late in infection. Increased TGF- $\beta$ mRNA expression and protein levels were also detected in the spleen; according to our results, this expression was associated with immunosuppressive mechanisms (Li et al. 1999, Nylén et al. 2007).

In addition to the involvement of TLR 2 and 4 in leishmaniasis, other TLRs, such as TLR3, TLR7 and TLR9, also operate in Leishmania recognition (Flandin et al. 2006, Schleicher et al. 2007, Paun et al. 2011). It was observed that TLR9 activation by Leishmania seems to be crucial in modulating the production of cytokines, such as IL-12 (Schleicher et al. 2007). According to these findings, we suggest that other TLRs could be involved in cytokine modulation during infection with $L$. chagasi.

In summary, our findings show that, in the acute phase of infection, there was a correlation between TLR2-4 expression, TNF- $\alpha$, IL-17, IL-10, TGF- $\beta$, and NO production and parasite load, which was high during this period of infection. In the final phase or chronic phase of infection, a correlation between low TLR2-4 expressions, lower TNF- $\alpha$, IL-17 and TGF- $\beta$ production and low parasite load was observed. In this period, we also detected increased production of IL-12, IFN- $\gamma$ and NO, which were likely involved in infection control. These findings suggest that $L$. chagasi interacted with TLR2-4 and that parasite infection led to cytokine modulation during the acute and chronic phases. Further studies will be conducted to confirm the involvement of TLRs in cytokine and NO production during experimental infection with $L$. chagasi.

\section{REFERENCES}

Agnello D, Lankford CSR, Bream J, Morinobu A, Gadina M, Shea JJO, Frucht DM 2003. Cytokines and transcription factors that regulate $\mathrm{T}$ helper cell differentiation: new players and new insights. J Clin Immunol 23: 147-161.

Anderson CF, Stumhofer JS, Hunter CA, Sacks D 2009. IL-27 regulates IL-10 and IL-17 from CD4 $4^{+}$cells in nonhealing Leishmania major infection. J Immunol 183: 4619-4627.

Ansari NA, Saluja S, Salotra P 2006. Elevated levels of interferongamma, interleukin-10 and interleukin- 6 during active disease in Indian Kala azar. Clin Immunol 119: 339-345.
Bacellar O, Brodskyn C, Guerreiro J, Barral-Netto M, Costa CH, Coffman RL, Johnson WD, Carvalho EM 1996. Interleukin-12 restores interferon-gamma production and cytotoxic responses in visceral leishmaniasis. J Infect Dis 173: 1515-1518.

Bacellar O, Faria D, Nascimento M, Cardoso TM, Gollob KJ, Dutra WO, Scott P, Carvalho EM 2009. IL-17 production in patients with American cutaneous leishmaniasis. J Infect Dis 200: 75-78.

Badaro R, Jones TC, Carvalho EM, Sampaio D, Reed SG, Barral A, Teixeira R, Johnson WD Jr 1986. New perspectives on a subclinical form visceral leishmaniasis. J Infec Dis 154: 1003-1011.

Barral A, Carvalho EM, Badaro R, Barral-Neto M 1986. Suppression of lymphocyte proliferative responses by sera from patients with American visceral leishmaniasis. Am J Trop Med Hyg 35: 735-742.

Becker I, Salaiza N, Aguirre M, Delgado J, Carrillo-Carrasco N, Kobeh LG, Ruiz A, Cervantes R, Torres AP, Cabrera N, González A, Maldonado C, Isibasi A 2003. Leishmania lipophosphoglycan (LPG) activates NK cells through Toll-like receptor 2. Mol Biochem Parasitol 130: 65-74.

Belkaid Y, Hoffmann KF, Mendez S, Kamhawi S, Udey MC, Wynn TA, Sacks DL 2001. The role of interleukin (IL)-10 in the persistence of Leishmania major in the skin after healing and the therapeutic potential of anti-IL-10 receptor antibody for sterile cure. J Exp Med 194: 1497-1506.

Belkaid Y, Piccirillo CA, Mendez S, Shevach EM, Sacks DL 2002. CD4 ${ }^{+}$ $\mathrm{CD} 25^{+}$regulatory $\mathrm{T}$ cells control Leishmania major persistence and immunity. Nature 420: 502-507.

Belosevic M, Finbloom DS, Van Der Meide, Slayter MV, Nacy CA 1989. Administration of monoclonal anti-IFN-gamma antibodies in vivo abrogates natural resistance of $\mathrm{C} 3 \mathrm{H} / \mathrm{HeN}$ mice to infection with Leishmania major. J Immunol 143: 266-274.

Bodgan C, Moll H, Solbach W, Röllinghoff M 1990. Tumor necrosis factor- $\alpha$ in combination with interferon- $\gamma$, but not with interleukin 4 activates murine macrophages for elimination of Leishmania major amastigotes. Eur J Immunol 20: 1131-1135.

Bradley JR 2008. TNF-mediated inflammatory disease. J Pathol 214: $149-160$.

Buffet PA, Sulahian A, Garin YJF, Nassar N, Derouin F 1995. Culture microtitration: sensitive method for quantifying Leishmania infantum in tissues of infected mice. Antimicrob Agents Chemother 39: 2167-2168.

Carvalho EM, Bacellar O, Barral A, Badaro R, Johnson Jr WD 1989. Antigen-specific immunosuppression in visceral leishmaniasis is cell mediated. J Clin Invest 83: 860-864.

Cillari E, Vitale G, Arcolco F, Agostino PD, Mocciaro C, Gambino G, Malta R, Stassi G, Giordano C, Milano S 1995. In vivo and in vitro cytokine profiles and mononuclear cell subsets in Sicilian patients with active visceral leishmaniasis. Cytokine 7: 740-745.

Cummings HE, Tuladhar R, Satoskar AR 2010. Cytokines and their STATs in cutaneous and visceral leishmaniasis. J Biomed Biotechonol 2010: 1-6.

Cunningham AC 2002. Parasitic adaptive mechanisms in infection by leishmania. Exp Mol Pathol 72: 132-141.

de Veer MJ, Curtis JM, Baldwin TM, DiDonato JA, Sexton A, McConville MJ, Handman E, Schofield L 2003. MyD88 is essential for clearance of Leishmania major: possible role for lipophosphoglycan and Toll-like receptor 2 signaling. Eur J Immunol 33: 2822-2831.

Desjeux P 2001. The increase in risk factors for leishmaniasis worldwide. Trans R Soc Trop Med Hyg 95: 239-243.

Dong C 2008. Th17 cells in development: an updated view of their molecular identity and genetic programming. Nat Rev Immunol 8: 337-348. 
Dye C 1996. The logic of visceral leishmaniasis control. Am J Trop Med Hyg 55: 125-130.

Fenech MF, Dunaiski V, Osborne Y, Morley AA 1991. The cytokinesis-block micronucleus assay as a biological dosimeter in spleen and peripheral blood lymphocytes of the mouse following acute whole-body irradiation. Mutat Res 263: 119-126.

Flandin JF, Chano F, Descoteaux A 2006. RNA interference reveals a role for TLR-2 and TLR3 in the recognition of Leishmania donovani promastigotes by interferon-gamma - primed macrophages. Eur J Immunol 36: 411-420.

Flo TH, Halaas O, Torp S, Ryan L, Lien E, Dybdahl B, Sundan A, Espevik T 2001. Differential expression of Toll-like receptor 2 in human cells. J Leukoc Biol 69: 474-481.

Gantt KR, Goldman TL, McCormick ML, Miller MA, Jeronimo SMB, Nascimento ET, Britigan BE, Wilson ME 2001. Oxidative responses of human and murine macrophages during phagocytosis of Leishmania chagasi. J Immunol 167: 893-901.

Gantt KR, Schultz-Cherry S, Rodriguez N, Jeronimo SMB, Nascimento ET, Goldman TL, Recker TJ, Miller MA, Wilson ME 2003. Activation of TGF- $\beta$ by Leishmania chagasi: importance for parasite survival in macrophages. J Immunol 170: 2613-2620.

Ghalib HW, Whittle JA, Kubin M, Hashim FA, el-Hassan AM, Grabstein KH, Trinchieri G, Reed SG 1995. IL-12 enhances Th1-type responses in human Leishmania donovani infections. J Immunol 154: 4623-4629.

Goto H, Prianti MG 2009. Immunoactivation and immunopathogeny during active visceral leishmaniasis. Rev Inst Med Trop Sao Paulo 5: 241-246.

Green LC, Wagner DA, Glogowski J 1982. Analysis of nitrate, nitrite, and $\left[{ }^{15} \mathrm{~N}\right]$ nitrate in biological fluids. Anal Biochem 126: 131-138.

Guedes PMM, Gutierrez FRS, Maia FL, Milanezi CM, Silva GK, Pavanelli WR, Silva JS 2010. IL-17 produced during Trypanosoma cruzi infection plays a central role in regulation parasite-induced myocarditis. PloS Negl Trop Dis 4: e604.

Hernandez-Pando R, Orozco H, Arriaga K, Sampieri A, Larriva-Sahd J, Madrid-Marina V 1997. Analysis of the local kinetics and localization of interleukin-1 alpha, tumour necrosis factor-alpha and transforming growth factor-beta during the course of experimental pulmonary tuberculosis. Immunol 90: 607-617.

Kaye PM, Svensson M, Ato M, Maroof A, Polley R, Stager S, Zubairi S, Engwerda CR 2004. The immunopathology of experimental visceral leishmaniasis. Immunol Rev 201: 239-253.

Kenney RT, Sacks DL, Gam AA, Murray HW, Sundar S 1998. Splenic cytokine responses in Indian kala-azar before and after treatment. J Infect Dis 177: 815-818.

Kostka SL, Dinges S, Griewank K, Iwakura Y, Udey MC 2009. IL-17 promotes progression of cutaneous leishmaniasis in susceptible mice. J Immunol 182: 3039-3046.

Kropf P, Freudenberg MA, Modolell M, Price HP, Herath S, Antoniazi S, Galanos C, Smith DF, Müller I 2004. Toll-like receptor 4 contributes to efficient control of infection with the protozoan parasite Leishmania major. Infect Immun 72: 1920-1928.

Kumar R, Pai K, Sundar S 2001. Reactive oxygen intermediates, nitrite and IFN-gamma in Indian visceral leishmaniasis. Clin Exp Immunol 124: 262-265.

Li J, Hunter CA, Farrell JP 1999. Anti-TGF-beta treatment promotes rapid healing of Leishmania major infection in mice by enhancing in vivo nitric oxide production. J Immunol 162: 974-979.

Liew FY, Li Y, Millott S 1990. Tumor necrosis factor-alpha synergizes with IFN-gamma in mediating killing of Leishmania major through the induction of nitric oxide. J Immunol 145: 4306-4310.

Maier T, Güell M, Serrano L 2009. Correlation of mRNA and protein complex biological samples. FEBS Lett 583: 3966-3973.
Medzhitov R 2007. Recognition of microorganisms and activation of the immune response. Nature 449: 819-826.

Mishra BB, Gundra UM, Teale JM 2008. Expression and distribution of Toll-Like receptors 11-13 in the brain during murine neurocysticercosis. J Neuroinflammation 5: 53.

Nylén S, Maurya R, Eidsmo L, Manandhar K, Sundar S, Sacks D 2007. Splenic accumulation of IL-10 mRNA in T cells distinct from $\mathrm{CD} 4{ }^{+} \mathrm{CD} 25^{+}$(Foxp3) regulatory $\mathrm{T}$ cells in human visceral leishmaniasis. J Exp Med 204: 805-817.

Paun A, Bankoti R, Joshi T, Pitha PM, Stäger S 2011. Critical role of IRF-5 in the development of T helper 1 responses to Leishmania donovani infection. PLoS Pathog 7: e1001246.

Pinelli E, Gonzalo RM, Boog CJ, Rutten VP, Gebhard D, del Real G, Ruitenberg J 1995. Leishmania infantum-specific T cell lines derived from asymptomatic dogs that lyse infected macrophages in a major histocompatibility complex-restricted manner. Eur $J$ Immunol 25: 1594-1600.

Ray M, Gam AA, Boykins RA 2000. Inhibition of interferon- $\gamma$ signaling by Leishmania donovani. J Infect Dis 181: 1121-1128.

Ribeiro de Jesus A, Luna T, Pacheco de Almeida R, Machado PR, Carvalho EM 2008. Pentoxifylline down modulate in vitro $\mathrm{T}$ cell responses and attenuate pathology in Leishmania and HTLV-I infections. Int Immunopharmacol 8: 1344-1353.

Robak T, Gladalska A, Stepien H 1998. The tumor necrosis factor family of receptors/ligands in the serum of patients with rheumatoid arthritis. Eur Cytokine Netw 9: 145-154.

Schleicher U, Liese J, Knippertz I, Kurzmann C, Hesse A, Heit A, Fischer JAA, Weiss S, Kalinke U, Kunz S, Bodgan C 2007. NK cell activation in visceral leishmaniasis requires TLR9, myeloid DCs, and IL-12 but is independent of plsmacytoid DCs. $J$ Exp Med 204: 893-906.

Sharma U, Singh S 2009. Immunobiology of leishmaniasis. Indian $J$ Exp Biol 47: 412-423.

Silvestre R, Silva AM, Cordeiro-da-Silva A, Ouaissi A 2009. The contribution of Toll-like receptor 2 to the innate recognition of a Leishmania infantum silent information regulator 2 protein. Immunol 128: 484-499.

Suffia IJ, Reckling SKR, Piccirillo CA, Goldzmid RS, Belkaid Y 2006. Infected site-restricted Foxp $3^{+}$natural regulatory T cells are specific for microbial antigens. J Exp Med 203: 777-788.

Tesmer LA, Lundy SK, Sarkar S, Fox DA 2008. Th17 cells in human disease. Immunol Rev 223: 87-113.

Theodos CM, Povinelli L, Molina R, Sherry B, Titus RG 1991. Role of tumor necrosis factor in macrophage leishmanicidal activity in vitro and resistance to cutaneous leishmaniasis in vivo. Infect Immun 59: 2839-2842.

Tuon FF, Amato VS, Bacha HA, Almusawi T, Duarte MI, Neto VA 2008. Toll-like receptors and leishmaniasis. Infect Immun 76: 866-872.

Vanden ES, Goriely S, De Wit D, Goldman M, Willens F 2006. Preferencial production of the IL-12 (p40)/IL-23(p19) heterodimer by dendritic cells from human newborns. Eur J Immunol 36: 21-26.

Verma S, Kumar R, Katara GK, Singh LC, Negi NS, Ramesh V, Salotra P 2010. Quantification of parasite load in clinical samples of leishmaniasis patients: IL-10 level correlates with parasite load in visceral leishmaniasis. PLOS ONE 5: e10107.

Watford WT, Hissong BD, Bream JH, Kanno Y, Muul L, O’Shea JJ 2004. Signaling by IL-12 and IL-23 and the immunoregulatory roles of STAT4. Immunol Rev 202: 139-156.

Wilhelm P, Ritter U, Labbow S, Donhauser N, Röllinnghoff M, Bodgan C, Körner H 2001. Rapidly fatal leishmaniasis in resistant C57BL/6 mice lacking TNF. J Immunol 166: 4012-4019. 